\title{
CLASS CONFLICT, FISCAL POLICY, AND WAGE-LED DEMAND: A MODEL OF KALECKI'S POLITICAL BUSINESS CYCLE
}

\author{
Giorgos Gouzoulis, Collin Constantinel
}

\begin{abstract}
This paper provides a demand-driven growth model of Kalecki's (1943) political business cycle. It incorporates the three fundamental assumptions that govern Kalecki's model: wage-led demand, the "reserve army of labor" effect, and capitalists' disproportionate power over fiscal policy. In our model, endogenous cycles are the outcome of capitalists' changing preferences over fiscal policy. Decreasing opposition to fiscal expansion by capitalists triggers the boom phase of the cycle, lest demand deficiency lead to a slowdown in accumulation. The downturn of the cycle is induced by capitalists' rising opposition to government spending, lest workers' growing political power at the peak of the cycle undermine their influence. This approach is unlike that taken by Goodwin and neoclassical PBC models, where a profit squeeze and the timing of elections or political ideologies determine cycles.
\end{abstract}

KEYWORDS: political business cycle, class struggle, income distribution

\section{INTRODUCTION}

The role of politics has been largely overlooked in the field of macroeconomic theory during the last decades. Even within the political economy tradition, where class conflict between capitalists and workers is central, little has been said about the capitalist-government nexus and its impact on macroeconomic performance and endogenous crises. This becomes even more evident in the

\footnotetext{
1 Giorgos Gouzoulis is at University College London, UCL Institute for Innovation and Public Purpose; e-mail: g.gouzoulis@ucl.ac.uk; Collin Constantine is at SOAS, University of London, Department of Economics; e-mail: constantine.collin@soas.ac.uk. The authors are grateful to Achilleas Mantes, Rob Calvert Jump, Rafael Ribeiro, Christina Wolf, James Wood, and two anonymous referees for their helpful comments and suggestions.
} 
macroeconomic modelling literature where political factors are absent. Even the heterodox political economy modelling literature implicitly supports the state-economy dualism perspective, which considers the political system as exogenous to the economy (Bandelj and Sowers 2010). This article contributes to the literature by providing the first formal macroeconomic model of Kalecki's (1943) political business cycle (PBC) to explicitly build on the state-economy embeddedness assumption.

In contrast to neoclassical scholars, political economists do recognize the endogenous nature of crises and business cycles. So far, formal macroeconomic models of endogenous crises have focused solely on economic factors, without introducing explicitly political economy factors. Examples of such models are the Marxian profit squeeze cycle of Goodwin (1967) and the debt crises models that originate in the work of Minsky (Nikolaidi 2017). Kalecki (1943) is the only exception within the literature to argue that macroeconomic instability can also arise endogenously due to political factors, under the following assumptions: capitalists' disproportionate power over fiscal policy, wage-led demand, and the Marxian "reserve army of labor" effect. Capitalists' decreasing opposition to fiscal expansion triggers the boom phase of the cycle, lest demand deficiency lead to a slowdown in accumulation. The downturn of the cycle is induced by capitalists' rising opposition to government spending, lest workers' growing political power at the peak of the cycle undermine their influence. Nevertheless, Kalecki did not provide a formal model of his class-conflict-driven PBC, thus the recent PBC models are built on the interpretations of Nordhaus (1975) and Hibbs (1977). These neoclassical micro-founded models reject Kalecki's core hypotheses, contending that $\mathrm{PBCs}$ are driven by exogenous factors, such as election cycles and political parties' partisan preferences (Dubois 2016). This constitutes a major departure from Kalecki (1943). From a political economy perspective these models introduce the role of politics but are clearly based on the state-economy dualism rather than on the state-economy embeddedness perspective. Recently, Blyth and Matthijs (2017) have highlighted the importance of Kalecki's (1943) PBC and recognize its endogenous nature, but they provide neither a precise analysis of its channels nor a formal model. This paper fills this gap in the literature.

Our paper provides a precise description and a simple formal macroeconomic model of our interpretation of Kalecki's original PBC, incorporating capitalists' socio-economic uncertainty and their power over fiscal policy into a wageled aggregate demand model. Thus, only political factors can endogenously destabilize the system. The cycles occur as capitalists manipulate fiscal policy to preserve the current favorable institutional setting, balancing between economic and political uncertainty. Our contribution is non-trivial since it 
offers a political-economy, non-profit-squeeze explanation of the 1970's crisis and the corresponding welfare state retrenchment, and the rise of neoliberalism. Moreover, such a general model is fundamental to understanding the dynamics of contemporary capitalism as it relates to the rise of Super Political Action Committees in the USA, growing recognition of the ability of firms to sue governments, and the increasing importance of money in politics.

The rest of the article is structured as follows. The second section examines the evolution of the PBC literature. The third section interprets Kalecki's (1943) $\mathrm{PBC}$ as an endogenous crisis theory in the context of a static demand-driven macroeconomic model. The fourth section discusses the empirical relevance of our model and its implications for the growth model perspective in a comparative political economy. Finally, the fifth section concludes.

\section{POLITICAL BUSINESS CYCLES: FROM KALECKI TO RATIONAL EXPECTATIONS}

More than seventy years ago, Kalecki's (1943) seminal article Political aspects of full employment became the cornerstone of PBC research. ${ }^{2}$ Based on the wage-led demand regime and the "reserve army of labor" hypothesis, Kalecki attempted to descriptively outline a behavioral endogenous business cycle mechanism in which growth is driven by capitalists' ever-changing preferences for government intervention, which in turn influence the political balance of power, and vice versa. A few decades later, Nordhaus (1975) endeavored - for the first time - to formally model a PBC, focusing more on the microeconomic level. More specifically, according to this neoclassical model cycles are generated by individual voters' adaptive preferences about unemployment and inflation, and their relationship with election cycles, given a policy-neutral government. Subsequently, Hibbs (1977) relaxes Nordhaus' restrictive assumption based on the policy neutrality of government by introducing the impact of political parties' ideological preferences on unemployment and inflation. The aim of this section is, first, to clarify the "mechanics" of Kalecki's PBC, and then to highlight its major discrepancies compared to the relevant neoclassical models.

2 Peculiarly enough, the relevant article in The New Palgrave Dictionary of Economics (2008) does not even mention Kalecki, in spite of Nordhaus' (1975) explicit acknowledgement of his contribution. 


\section{Political aspects of full employment}

The original version of Kalecki's article appeared in The Political Quarterly in 1943, while a slightly revised version was included in his Selected Essays on the Dynamics of the Capitalist Economy (Kalecki 1971). Compared to his more mature writings (e.g. Kalecki 1954), this work depicts a different viewpoint of Kalecki's macroeconomics analysis following a less formal economistic but more interdisciplinary approach, heavily relying upon class-based, political microfoundations. In particular, his PBC mechanism does offer crucial theoretical insights into the dependency relationship between capitalists and the government, and into the political-uncertainty-macroeconomy-class conflict nexus, building on the general principles of his wage-led demand assumption.

Kalecki begins his analysis by stating that achieving full employment via government spending is technically feasible and also enhances macroeconomic stability, given a wage-led demand regime (Kalecki 1943, p. 324). From a purely economistic perspective, such a scenario benefits both social classes. However, in a real-world, complex socio-economic system, decisions and preferences are not formed solely on the basis of (macro)economic performance. According to Kalecki (ibid.), capitalists' stance concerning government intervention depends on several ideological and political aspects, such as: (i) Their idealistic opposition to the direct interference of the government in the labor market; (ii) Their dislike of government spending programs that include public investment and mass consumption subsidies; and (iii) Their fear that permanent full employment will trigger major social and political changes, leaving aside the positive growth effects. To analyze the dynamics of his political business cycle model, Kalecki describes the underlying behavioral norms and their macroeconomic and political implications but without providing a formal model.

Starting from the downward phase of the cycle, employment, wages, and the rate of growth of the economy steadily decrease. At this point, even the most dogmatic capitalists agree that government must intervene to overcome this plateau (Kalecki 1943, p. 328). Their initial demand is that government supported by their "economic experts" - should stimulate private investment through supply-side policies, which in Kalecki's demand-driven framework fails to sustainably boost growth. ${ }^{3}$ Given the failure of the supply-side stimulus, the recession deepens and reaches a stagnation stage, in which even profit realization issues arise. Under these conditions, capitalists realize that a demand boost is needed; therefore, they consent to a rise in public investment to fight

3 Kalecki reasonably argues that, even from a purely supply-side perspective, such a policy program cannot be effective since interest rates or income taxes - by definition - cannot be ever decreasing. 
unemployment (Kalecki 1943, p. 329). Kalecki also contends that capitalists, in principle, prefer public investment rather than consumption subsidies, since the latter violate the fundamentalist free-market ideal according to which workers "...shall earn [their] bread in sweat" (Kalecki 1943, p. 326). In this regard, two observations can be made: First, government can exercise both supply and demand-side policies, but its ability to choose and implement them depends on capitalists' preferences; Second, for pragmatic reasons capitalists' ideological opposition to demand-side intervention falls in periods of secular stagnation.

Following Kalecki's rationale, let us suppose that public investment has a positive impact on employment and real wages due to the diminishing reserve army effect (ibid.). Given the wage-led demand hypothesis, the rise in real wages boosts growth and engenders a wage-led sustainable recovery. In a profit-led demand framework, a crisis would occur in the form of a profit squeeze, since a rising wage share depletes firms' internal sources of finance. However, in Kalecki's wage-led demand framework, a profit squeeze crisis cannot occur. Thus the question: what are the endogenous forces that generate cycles in a wageled regime? Assuming a successful public-driven, wage-led recovery scenario, the economy reaches close to full employment. After a reasonable period of persistently low unemployment conditions, Kalecki (1943, p. 329) maintains that business leaders demand a contraction in government spending, i.e., a return to a laissez-faire regime. ${ }^{5}$ This policy demand is driven by potential socio-political changes that are linked to lasting low unemployment. The negative demand shock of this public investment contraction directly harms employment, and thereafter, real wages and growth; leading to a recession.

It follows that capitalists' preferences regarding the extent of government intervention can generate cycles in a wage-led demand regime. For example, at the peak of the cycle, the reserve army of labor becomes depleted; job insecurity decreases, and workers' bargaining power peaks. Labor's short-term goal of economic "survival" has been achieved and, collectively, labor hopes to influence government policy. But a downward cycle is induced as the capitalist class undermines labor's solidarity by lobbying for a return to a laissez-faire regime. This "laissez-faire shock" brings macroeconomic instability and workers shift their focus to short-term economic goals; i.e., the struggle to retain their jobs. In a sense, capitalists' rising socio-political uncertainty leads them to sacrifice

4 In practice, the post-WWII deployment of the welfare state shows that Kalecki's assertion about that particular issue is not entirely correct, inasmuch as even consumption subsidies may be acceptable.

5 Sawyer (1985, p. 140) contends that such a reasonable period is "...much more than the two or three years of the boom part of the business cycle," whilst Streeck (2011) argues that the point at which capitalists react adversely cannot be accurately predicted as it is subject to historical circumstances. A historical example of such a "reasonable period" could be the post-WWII "Golden Age" era. 
sales in the short-term (i.e. profitability) to secure the current balance of power in the long-term. By "current balance of power" we mean that capitalists are the only social class that is cohesive enough to effectively advance its policy agenda. As the economy sinks back into recession in the absence of government intervention, the fiscal policy agenda debate arises again, and the cycle repeats itself (see Figure 1).

Figure 1. Kalecki's Political Business Cycle

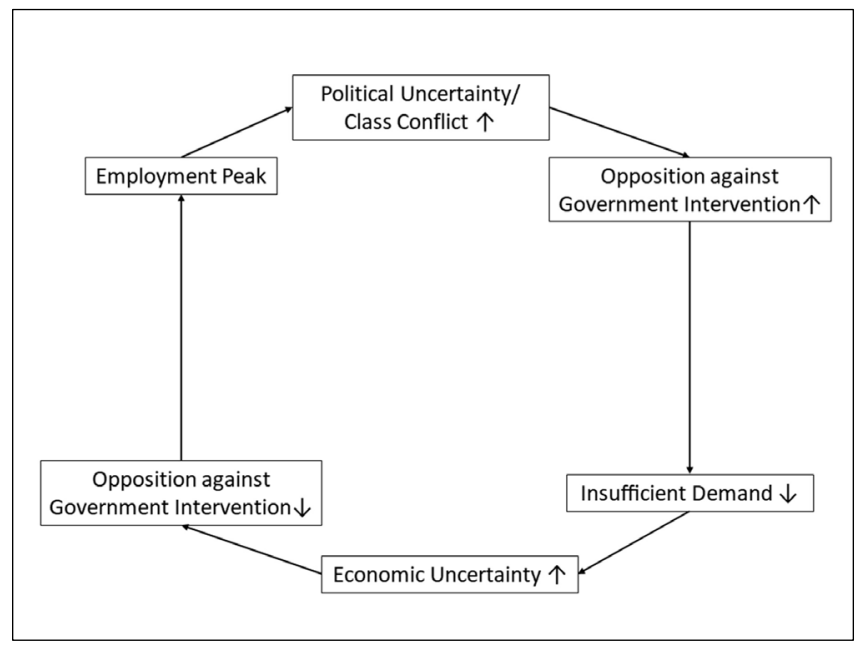

source: authors' compilation

\section{Neoclassical PBC models}

For several decades, Kalecki's contribution and the issue of PBCs in general was overlooked both by neoclassical and heterodox economists. Nordhaus (1975, p. 182) revisited the issue of politically-driven cycles by rejecting Kalecki's assumption of capitalists' disproportional control over government. The economy in this early formal model is constituted of identical voters and opportunistic policymakers/political parties. The objective of voters is to minimize a Phillips-curve-based, unemployment-inflation-trade-off loss function, whilst political parties want to maximize the probability of re-election and are indifferent in terms of economic policy. Policy is conducted based on an expectations-augmented Phillips curve, which indicates that an unanticipated 
increase in money supply may boost employment in the short term. Given that framework, Nordhaus argues that, as elections approach, policy makers attempt to decrease unemployment through monetary policy shocks to enhance their chances of re-election. As the election period passes, the government's opportunistic incentive to actively fight unemployment vanishes, and as a result, a slump follows. Later on, Hibbs (1977) modified Nordhaus' model by incorporating more sophisticated political parties, which do have preferences about target unemployment and inflation rates due to their political ideologies. Now, identical voters' loss function is also affected by the policy agenda of each party as well. Accordingly, Hibbs' model exhibits cycles due to the partisan policy preferences of the ruling party. When a left-wing party is in power, its ideology indicates a more expansionary monetary policy approach, while a right-wing government's ideology centers on keeping inflation low.

Both opportunistic (Nordhaus 1975) and partisan (Hibbs 1977) PBC models have been criticized for including "naïve" non-rational voters and for their exclusive focus on monetary policy (Drazen 2001). The rise of rational expectations and information asymmetry approaches within the neoclassical tradition affected the evolution of PBC models too. Alesina (1987) alters Hibbs' partisan model by incorporating rationally adjusted inflation expectations, which implies that the impact of pre-election monetary shocks will be even more short-lived. Moreover, Rogoff and Sibert's (1988) and Rogoff's (1990) influential opportunistic PBC models embody voters with rational expectations, but also incomplete information about fiscal policy's consequences. During the pre-election period, policymakers take advantage of voters' ignorance about the long-run deficit implications of expansionary monetary policy, which eventually leads to cycles in economic activity.

As shown in the previous sub-section, for Kalecki (1943) the PBC is driven endogenously by the feedback among fiscal policy, demand, and capitalists' struggle to preserve their control over government. Evidently, the neoclassical PBC models neglect the role of social class conflict, effective demand, and socio-economic uncertainty by concentrating exclusively on exogenous drivers, such as the timing of elections and voters who minimize purely economistic, non-behavioral loss functions. Still, no formal PBC model exists outside the neoclassical tradition - neither in a growth, nor in a system dynamics modelling context - especially along the lines of Kalecki's assumptions of wage-led demand and the disproportional influence of the ruling class over public policy. 


\section{KALECKI'S PBC AS AN ENDOGENOUS CRISIS THEORY}

In the past, political economists and social scientists have discussed several aspects of Kalecki's PBC, but none provide a detailed explanation of its endogenous mechanics (see previous section) or a formal model. Feiwel (1974) and Sawyer (1985) narratively discussed the main aspects and implications of Kalecki's arguments, whereas Arestis and Skuse (2003) debated the relevance of his contribution with respect to the current policy agenda and the development of the financial sector. Oddly enough, the discussions of Feiwel (1974), Sawyer (1985), and Arestis and Skuse (2003) involved the exogenous impact of election cycles, among other things, in accordance with Nordhaus (1975). This is unlike Kalecki (1943), who does not mention elections at all. More recently, Streeck (2011), and Blyth and Matthijs (2017) recognize the endogenous nature of Kalecki's PBC, stressing the importance of the bidirectional feedback between politics and the macroeconomy, but these scholars have little to say about the precise endogenous mechanisms at work. ${ }^{6}$

The aim of this section is to provide a simple, intuitive formal model of Kalecki's PBC, building on the neo-Kaleckian wage-led demand framework (Lavoie and Stockhammer 2013). First, we introduce a behavioral government spending function into a static aggregate demand-driven model in order to discuss the macroeconomic implications of politically driven fiscal policy expansions and contractions. ${ }^{7}$ Extending such a simple closed-economy model through the inclusion of a Kaleckian behavioral government spending function, we derive the following aggregate demand function:

$$
Y=C(Y, W S, G c s)+I(Y, W S)+G(\rho)
$$

where is output, is consumption, is private investment, is government expenditure, is the wage share, is government expenditure in the form of consumption subsidies, while is the capitalists' degree of opposition to more expansionary fiscal policy. Following the Kaleckian growth literature (Lavoie and Stockhammer 2013), we assume that demand is wage-led. Accordingly, an increase in real wages boosts consumption $(\partial C / \partial W S>0)$ due to workers'

6 Boddy and Crotty (1975) also discuss Kalecki's PBC, recognizing that it is endogenous, and study empirically such short-run cycles in the US economy, but their analysis relies upon the Marxian profit-led framework which contradicts Kalecki's wage-led assumption, as shown earlier.

7 The Kaleckian growth literature largely overlooks fiscal policy, with the exception of Obst et al. (2017) who incorporate the impact of fiscal policy into an open-economy, Bhaduri-Marglin (1990) model, focusing on estimating the cross-country effects of changes in government spending and income distribution, in a panel data context. 
higher marginal propensity to consume and simultaneously harms investment through lower profitability $(\partial \rho / \partial E>0)$. The wage-led hypothesis implies that consumption is more sensitive to functional income distribution shocks than investment $(|\partial C / \partial W S|>|\partial I / \partial W S|)$, therefore higher wage shares stimulate economic growth. Apparently, demand level $(Y)$ has a positive multiplier effect on both components of private domestic demand, i.e. $\partial C, \partial I / \partial Y>0$.

As argued in Section 2, the driving force of fluctuations in our model is capitalists' ever-changing opposition to government intervention $(\rho)$. Class conflict among industrial capitalists, rentiers, and workers has been at the core of the political economy approach; however, the capitalists-government nexus remains relatively unexplored. Our main contribution is the introduction of a behavioral government spending function in which the parameter negatively affects public spending $(\partial G / \partial \rho<0)$, as Kalecki (1943) contends. Furthermore, we purposely incorporate only one parameter, depicting Kalecki's view on capitalists' disproportional power over public policy decisions. We do not include any parameter for workers' influence, assuming that at this stage it is negligible. Later on, we argue that this complexity comes into the picture at the peak of the $\mathrm{PBC}$ and is the trigger for the change in the stance of capitalists against government intervention.

At this stage, a reasonable question is how the capitalist class derives its power over each government. Kalecki himself stresses that capitalists influence fiscal policy decisions by advocating their interests through their "economic experts." Such a strategy has been identified as an important lobbying tactic, among others, in the corporate politics literature (Hillman and Hitt 1999). McMenamin (2012) suggests that firms may act pragmatically in terms of their politics, rather than in a partisan way, attempting to influence public policy through lobbying, but also through cash donations to the entire political spectrum. The empirical part of this study reports empirical evidence that shows how Australian and Canadian firms tend to act pragmatically, funding ideologically diverse parties. A similar argument has also been presented by Tripathi et al. (2002). These scholars claim that more powerful social groups, like large corporations, prefer to directly promote their agendas by funding different political parties, rather than relying on election cycles. Goerres and Höpner (2014) also confirm empirically the argument that firms are politically pragmatic, providing econometric evidence that shows how automobile firms in Germany chose to distribute their donations to the entire political spectrum between 1984 and 2005. In a more recent paper, Tahoun and Vasvari (2016) report similar empirical findings concerning the political contributions of private financial institutions in the USA. It follows that Kalecki's early argument about capitalists' disproportionate power over public policy finds empirical support, contradicting the fundamental assumptions 
of Nordhaus (1975), Hibbs (1977), and the contemporary neoclassical PBC modelling literature, which neglect agents' heterogeneity, power, and politics.

Henceforth, for the purpose of this model, we define a capitalist-dependent government à la Kalecki, as the institution that, in principle, ought to actively pursue macroeconomic stability through fiscal policy, ${ }^{8}$ but which is confined by ruling class policy preferences. In contrast to Hibbs, in this model ideological differences among political parties are of minor importance. ${ }^{9}$ As a further step, we assume that the composition of total government spending is of the following form:

$$
G=G i+G c s+c
$$

where $G_{i}$ is public investment, and is the remaining constant part, which represents the minimum expenditure required for government's basic functions (e.g. ministry staff). Though Kalecki (1943, p. 326) mentions consumption subsidies as a non-acceptable measure of expansionary fiscal policy based on the Golden Age experience (Glyn et al. 1990), we consider that government may use both types of demand-oriented fiscal policy tools. Imposing the classic hypothesis that workers do not save, a rise in consumption subsidies $\left(G_{C S}\right)$ leads to an equal increase in total consumption (C); i.e., $\partial C / \partial G_{C S}>0$. To close our model, we must specify the distribution of factor income shares (WS), capitalists' opposition to government intervention $(\rho)$, and the employment rate $(E)$ :

$$
\begin{gathered}
W S=W S(E) \\
\rho=\rho(E) \\
E=E(Y)
\end{gathered}
$$

The wage share is a function of the reserve army of labor, depending positively on the employment rate $(\partial W S / \partial E>0)$, as the risk of labor substitution decreases when the employment rate rises. Given the analysis of Kalecki's PBC in Section 2, parameter $\rho$ also depends positively on the employment rate $(\partial \rho / \partial E>0)$ since a persistently high employment rate indicates fiercer sociopolitical class conflict, i.e., increased political uncertainty for the ruling class.

\footnotetext{
8 For example, the European Union (EC 2000) has explicitly defined full employment as one of its primary macroeconomic goals.

9 Indeed, the recent economic policy debate regarding the Eurozone crisis has shown emphatically how politically restricted governments are, regardless of their ideologies.
} 
Last, the employment rate is assumed to be endogenously determined by the level of output $(\partial E / \partial Y>0)$.

Along the lines of our interpretation of Kalecki's PBC, we begin our scrutiny from the secular stagnation stage where demand is in "freefall" and government still does not intervene. ${ }^{10}$ As demand decreases, the employment rate falls as well, leading to further reductions in real wages due to the reserve army effect. Under a wage-led regime, the fall in the labor share hampers growth through relatively stronger negative consumption effects. In this respect, with the economy in decline - due to our assumption of endogenously-determined employment - the ruling class' opposition to government intervention ( $\rho$ ) gradually diminishes. From a microeconomic perspective, in a wage-led regime constantly shrinking demand deteriorates capitalists' economic prospects and they temporarily abandon their idealistic anti-interventionist logic to achieve their short-term economic goals, i.e., sales. While $\rho$ falls, the government is encouraged/lobbied to exercise more drastic fiscal policy. Accepting Kalecki's (1943, pp. 328-329) argument on the ineffectiveness of purely supply-side policies, we focus exclusively on the effects of demand-side policy tools, i.e. public investment and consumption subsidies. An increase in the former has a direct positive effect on employment, ${ }^{11}$ which means that the size of the reserve army decreases, and labor's bargaining power rises. In turn, this process positively affects real wages and boosts consumption expenditure and growth. As argued above, under the assumption that workers do not save, the case for consumption subsidies is straightforward, since they have a direct positive impact on total consumption. This dual positive demand shock also has second-round effects through multiplier effects on consumption and investment that trigger wage-led recovery. Needless to say, the process of macroeconomic stabilization cannot be achieved at once, so government actively sustains aggregate demand, as long as capitalists' resistance remains low.

Figure 2. Fiscal policy-driven wage-led recovery

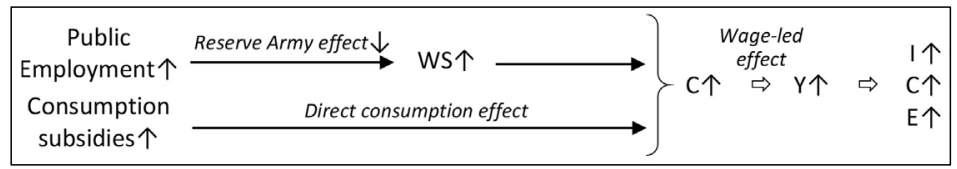

source: authors' compilation

10 This means ; i.e., that government spends nothing more than the minimum required.

11 We presume that these public investment projects hire unemployed workers, rather than compete with private firms to hire their current employees. 
As the economy reaches and remains at (near) full capacity, a behavioral change occurs at the microeconomic level: both social classes shift their focus to their long-term political goals. Capitalist opposition to government intervention begins to rise once again inasmuch as workers start gaining class consciousness and attempt to establish their own channel of influence over government. The workers' goal at this stage is to pursue favorable structural reform. In the technical terms of our model, this can be translated into a potential restructuring of the government spending equation, which would include a second behavioral parameter for the working class' power over public policy. As highlighted earlier, since such a political procedure is time-consuming, capitalists refocus on their long-term political goals in order to avoid this transformation, capitalizing on their preexisting relationship with government. Ergo, steadily rises, as the ruling class becomes "boom tired," inducing simultaneous cutbacks in public investment and consumption subsidies. Ceteris paribus, this dual government spending contraction has two direct implications: First, a decrease in employment; Second, the direct shrinkage of total consumption expenditure. The rise in unemployment deteriorates the bargaining position of workers, thus real wages fall. Given our wage-led demand assumption, this shift in functional income distribution towards profits leads to a slowdown in accumulation. Thereafter, investment and consumption expenditure decline further due to the multiplier effects, triggering economic downturn.

Figure 3. Government-spending-contraction-induced recession

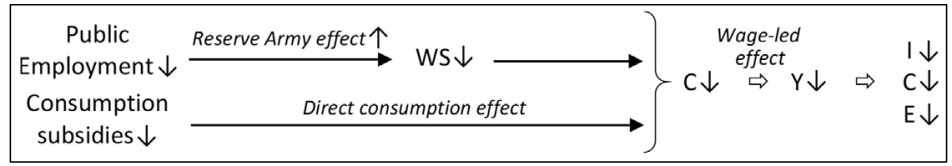

source: authors' compilation

This change in capitalists' stance against government intervention is interpreted as their political endeavor to maintain the current institutional setting, i.e., the current balance of power. This has been identified as one of the main objectives of firms' politics (e.g. Hall 1986; Fligstein 2001; Hall and Thelen 2009; Jullien and Smith 2011). The main contribution of this paper is that it assigns the role of the driver of an endogenous $\mathrm{PBC}$ to this particular behavioral assumption. Empirically, the idea of a government spending-driven cycle is not irrelevant; for instance, it is consistent with the experience in the USA over the period 1970-2001. According to Sherman (2015, pp. 116-118), public spending induced the business cycle upswings during that era, with 
government expenditure peaking before output. This is similar to the Kaleckian political business cycle described above.

\section{COMPARATIVE POLITICAL ECONOMY, ENDOGENOUS CRISES, AND POWER FROM A GROWTH MODEL PERSPECTIVE}

Introducing the government sector, following Kalecki (1943), into the neoKaleckian demand-driven model has important implications for the growth model perspective in comparative political economy. Baccaro and Pontusson (2016) challenge the relevance of the dominant paradigm in comparative political economy, i.e., the "Varieties of Capitalism" approach (Hall and Soskice 2001), pinpointing that it overlooks the role of income distribution. Instead, they reasonably claim that cross-country discrepancies can be better understood from a growth model perspective; i.e., through the analysis of the relative effects of changes in income distribution on the components of aggregate demand, building on the growth model of Bhaduri and Marglin (1990). However, an important shortcoming is that they do not consider explicitly the role of politics and government spending - as the authors themselves note. ${ }^{12}$ Accordingly, Baccaro and Pontusson (2016) do not discuss how income distribution affects class struggle, fiscal policy, and political instability within the growth model approach. We have addressed this issue by explicitly introducing the interaction between class conflict and government intervention into the growth model framework. Our perspective offers important insights about endogenous crises, power, and political instability.

In profit-led demand regimes, where investment is more sensitive than consumption to changes in income distribution, rising social and economic inequality leads to economic efficiency, but through a socially unsustainable growth model. Hence, the prerequisite for economic growth in profit-led economies creates the conditions for a social crisis. Contrariwise, in wage-led demand regimes decreasing social and economic inequality gives rise to an economically stable growth model. However, as outlined in the previous sections, prolonged economic stability and economic equality increase capitalists' political uncertainty, thus from their point of view it is politically unsustainable. This perspective highlights that a social democratic, pro-labor agenda may face opposition in both regimes but for different reasons. In profit-led economies,

12 In a more recent paper, Baccaro and Pontusson (2018) discuss politics but with a focus on partisan politics (Hibbs 1977) rather than following Kalecki's class conflict-based politics. 
squeezing wages engenders both economic efficiency and more power for the capitalist class. In wage-led economies, there is a trade-off between economic efficiency and power, depending on the phase of the cycle.

Baccaro and Pontusson (2016) in their empirical discussion argue that the transition from Fordism to neoliberalism was a transformation of demand regimes from wage-led to profit-led (private-investment-driven). However, this argument does not find empirical support. The majority of econometric studies on demand regimes show that demand was wage-led in most economies during the Fordist regime as well as in neoliberalism (e.g. Stockhammer and Stehrer 2011; Onaran and Galanis 2014; Stockhammer et al. 2018). Karabarbounis and Neiman $(2014$, p. 70$)$ report evidence that the wage share has declined since the mid-1970s; i.e., since the rise of neoliberalism on a global scale..$^{13}$ If the neoliberal regime has been profit-led, then the decreasing wage share would have resulted in higher growth. Yet, the global growth rate appears to have followed a declining trend since 1973, as reported in Figure 4.

Figure 4. Global growth rate (\%), 1960-2017

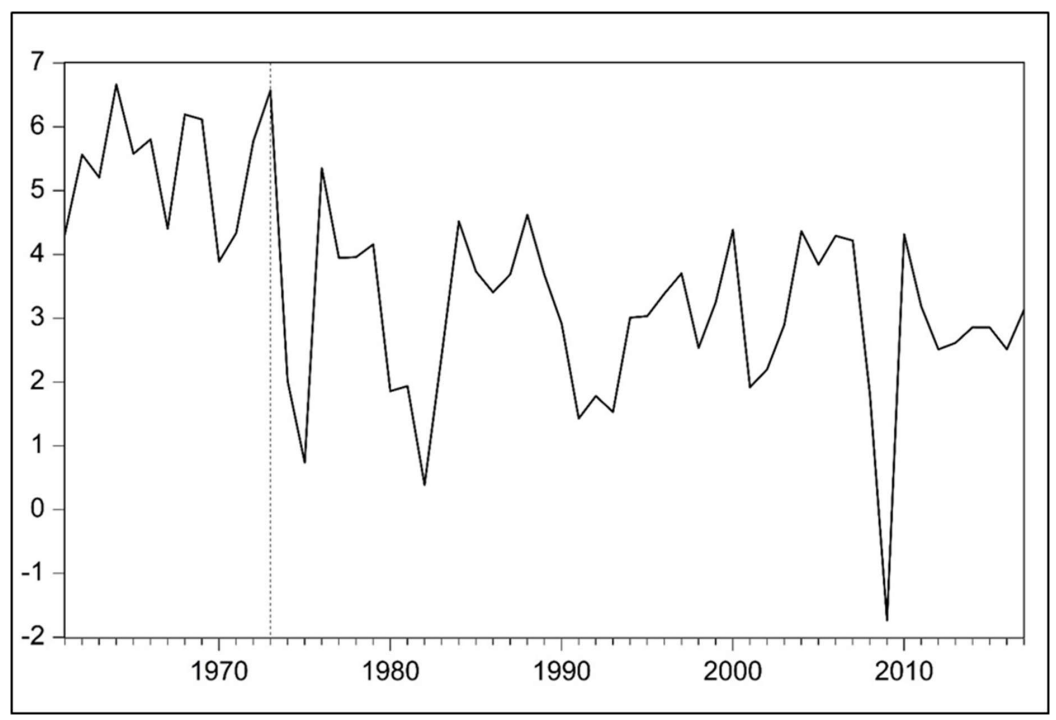

source: World Bank (https://data.worldbank.org/indicator/ny.gdp.mktp.kd.zg)

13 The authors report that this also holds at the individual country level over the same period, providing evidence for the USA, China, Japan, and Germany (Karabarbounis and Neiman 2014, p. 71). 
According to our model and given the empirical results of the demand regimes literature, the 1970's crisis was not a purely economic crisis, but rather a political one. As demand has been wage-led, our thesis is that the 1970's crisis was the outcome of the shift from the pro-labor policies of the Fordist era to the procapital policies of neoliberalism. For instance, evidence for such a politicallymotivated policy shift during that period in the USA is provided by Akard (1992). Also, Glyn and Sutcliffe (1972, pp. 172-188) report a pro-capital policy shift in the UK in the late 1960s - early 1970s, arguing that it was the capitalist class' response to workers' growing political power during the golden age. In this regard, we argue that neoliberalism can be seen as the downward phase of a Kaleckian PBC, the upward phase of which was the Fordist era.

\section{CONCLUSIONS}

During the past four decades, political business cycle models have grown significantly (Dubois 2016), building on the contributions of Nordhaus (1975) and Hibbs (1977), rather than on Kalecki's (1943) original work. Such models do depart from the purely economistic nature of most formal models by including the impact of politics on macroeconomic policy, but they still treat the political system as exogenous. More precisely, the neoclassical PBC models generate cycles because of two exogenous factors: (1) The timing of elections, which encourages government to enhance its prospects of re-election through fiscal expansion, and (2) The ideology of the ruling political party. In contrast, as argued in this paper, Kalecki perceived PBCs as endogenous cycles driven by the ruling class' varying resistance against government intervention, which in turn depends on the bidirectional feedback between the state of the macroeconomy and the political balance of power between workers and capitalists. Recently, the endogenous nature of Kalecki's PBC has been acknowledged by political economists from the fields of economic sociology and global political economy (Streeck 2011; Blyth and Matthijs 2017), but, until now, none has scrutinized the precise channels through which this cycle operates or provided a formal model.

The main contributions of this paper are as follows. It provides a precise explanation of how Kalecki's PBC works, demonstrates why it is fundamentally different from the neoclassical PBC models, and formalizes it in the context of a neo-Kaleckian demand-driven growth model. The boom phase of the cycle is triggered by capitalists' decreasing opposition to fiscal expansion as wage stagnation in a wage-led economy leads to a slowdown in accumulation, increasing their economic uncertainty. The downturn of the cycle is induced by 
the ruling class' increasing opposition to government spending, which increases workers' political power at the peak of the cycle and, by extension, political uncertainty for the capitalist class. In other words, capitalists become "boom tired" for political rather than economic reasons. The central mechanism is that capitalists have disproportionate power over government policy through lobbying and Super Political Action Committees during all phases of the business cycle. Thus, business cycles emerge because of capitalists' attempts to strike a balance between economic uncertainty - during the downturn phase - and political uncertainty - during the boom-peak phases - through the manipulation of fiscal policy in order to preserve the pro-capital institutional setting.

We argue that future macro models must build on the state-economy embeddedness hypothesis and account for endogenous political factors that can affect macroeconomic performance, and vice versa. Further, possible extensions of our model include the incorporation of central banks' monetary policy rule/s and the relationship between Kalecki's PBC and the rise of populism and the far-right.

\section{REFERENCES}

Akard, P. J. (1992), "Corporate mobilization and political power: The transformation of US economic policy in the 1970s", American Sociological Review, Vol. 57, No. 5, pp. 597-615.

Alesina, A. (1987), "Macroeconomic policy in a two-party system as a repeated game", The Quarterly Journal of Economics, Vol. 102, No. 3, pp. 651-678.

Arestis, P. - Skuse F. (2004), "The relevance of Kalecki's 'Political Aspects of Full Employment' to the twenty-first century", In: Sadowski, Z. L. Szeworski, A., eds, Kalecki's Economics Today, London, UK, Routledge.

Baccaro, L. - Pontusson, J. (2016), "Rethinking Comparative Political Economy: The Growth Model Perspective", Politics and Society, Vol. 44, No. 2, pp. 175207.

Baccaro, L. - Pontusson, J. (2018), “Comparative political economy and varieties of macroeconomics", Max Planck Institute for the Study of Societies, MPIfG Discussion Paper 18/10.

Bandelj, N. - Sowers, E. (2010), Economy and State, Cambridge, UK, Polity Press.

Bhaduri, A. - Marglin S. (1990), "Unemployment and the Real Wage: The Economic Basis for Contesting Political Ideologies", Cambridge Journal of Economics, Vol. 14, No. 4, pp. 375-93. 
Blyth, M. - Matthijs, M. (2017), "Black swans, lame ducks, and the mystery of IPE's missing macroeconomy", Review of International Political Economy, Vol. 24, No. 2, pp. 203-231.

Boddy, R. - Crotty, J. R. (1974), "Class Conflict and Macro-policy: The Political Business Cycle”, Review of Radical Political Economics, Vol. 7, No. 1, pp. $1-19$.

Drazen, A. (2001), "The political business cycle after 25 years", In: Bernanke,

B. S. - Rogoff, K., eds, NBER Macroeconomics Annual 2000, Volume 15, Cambridge, MA, MIT Press, pp. 75-138.

Dubois, E. (2016), "Political Business Cycles 40 Years after Nordhaus", Public Choice, Vol. 166, No. 1-2, pp. 235-259.

Durlauf, S. - Blume, S. (eds) (2008), The New Palgrave Dictionary of Economics ( $2^{\text {nd }}$ ed.), London, UK, Palgrave Macmillan.

EC (2000), "Lisbon European Council 23-24 March 2000. Presidency conclusions", EU European Council. http://aei.pitt.edu/43340/

Feiwel, G. R. (1974), "Reflection on Kalecki's Theory of Political Business Cycle", Kyklos, Vol. 27, No. 1, pp. 21-48.

Fligstein, N. (2001), The Architecture of Markets, Princeton, NJ, Princeton University Press.

Glyn, A. - Hughes, A. - Lipietz, A. - Singh, A. (1990), "The Rise and Fall of the Golden Age", In: Marglin, S. A. - Schor, J. B., eds, The Golden Age of Capitalism. Reinterpreting the Post-War Experience, Oxford, UK, Clarendon Press.

Glyn, A., - Sutcliffe, R. (1972), British Capitalism, Workers and the Profit Squeeze, London, UK, Penguin.

Goerres, A. - Höpner, M. (2014), "Polarizers or landscape groomers? An empirical analysis of party donations by the 100 largest German companies in 1984-2005", Socio-Economic Review, Vol. 12, No. 3, pp. 517-544.

Goodwin, R. M. (1967), “A Growth Cycle”, In: Feinstein, C. H., ed., Socialism, Capitalism and Economic Growth: Essays presented to Maurice Dobb, Cambridge, UK, Cambridge University Press.

Hall, P. A. - Soskice, D. (Eds.) (2001), Varieties of capitalism: The institutional foundations of comparative advantage, Oxford, UK, Oxford University Press. Hall, P. A. - Thelen, K. (2009), "Institutional change in varieties of capitalism", Socio-Economic Review, Vol. 7, No. 1, pp. 7-34.

Hall, P. A. (1986), Governing the Economy: The Politics of State Intervention in Britain and France, Cambridge, UK, Polity Press.

Hibbs, D. A. (1977), "Political parties and macroeconomic policy", The American Political Science Review, Vol. 71, No. 4, pp. 1467-1487. 
Hillman, A. J. - Hitt, M. A. (1999), "Corporate political strategy formulation: A model of approach, participation, and strategy decisions", The Academy of Management Review, Vol. 24, No. 4, pp. 825-842.

Jullien, B. - Smith, A. (2011), "Conceptualizing the role of politics in the economy: industries and their institutionalizations", Review of International Political Economy, Vol. 18, No. 3, pp. 358-383.

Kalecki, M. (1943), "Political aspects of full employment", The Political Quarterly, Vol. 14, No. 4, pp. 322-331.

Kalecki, M. (1954) Theory of Economic Dynamics, London, UK, Allen and Unwin.

Kalecki, M. (1971) Selected Essays on the Dynamics of the Capitalist Economy, 1933-1970, Cambridge, UK, Cambridge University Press.

Karabarbounis, L. - Neiman, B. (2013), "The global decline of the labor share", The Quarterly Journal of Economics, Vol. 129, No. 1, pp. 61-103.

Lavoie, M. - Stockhammer, E. (2013), "Wage-led Growth: Concept, Theories and Policies", In: Lavoie, M. - Stockhammer, E., eds, Wage-led Growth: An equitable strategy for economic recovery, London, UK, Palgrave Macmillan.

McMenamin, I. (2012), "If money talks, what does it say? Varieties of capitalism and business financing of parties", World Politics, Vol. 64, No. 1, pp. 1-38.

Nikolaidi, M. (2017), "Three decades of modelling Minsky: what we have learned and the way forward", European Journal of Economics and Economic Policies: Intervention, Vol. 14, No. 2, pp. 222-237.

Nordhaus, W. D. (1975), "The political business cycle", The Review of Economic Studies, Vol 42, No. 2, pp. 169-190.

Obst, T. - Onaran, Ö. - Nikolaidi, M. (2017), "The effect of income distribution and fiscal policy on growth, investment, and budget balance: the case of Europe", Greenwich Papers in Political Economy, University of Greenwich, No. 43.

Onaran, Ö. - Galanis, G. (2014), "Income distribution and growth: a global model", Environment and Planning A, Vol. 46, No. 10, pp. 2489-2513.

Rogoff, K. - Sibert, A. (1988), "Elections and macroeconomic policy cycles", The Review of Economic Studies, Vol. 55, No. 1, pp. 1-16.

Rogoff, K. (1990), "Equilibrium political budget cycles", The American Economic Review, Vol. 80, No. 1, pp. 21-36.

Sawyer, M. C. (1985), The Economics of Michat Kalecki, Armonk, NY, M. E. Sharpe.

Sherman, H. J. (2015), The Roller Coaster Economy: Financial Crisis, Great Recession, and the Public Option: Financial Crisis, Great Recession, and the Public Option, New York, NY, Routledge. 
Stockhammer, E. - Rabinovich, J. - Reddy, N. (2018), "Distribution, wealth and demand regimes in historical perspective. USA, UK, France and Germany, 1855-2010", Post-Keynesian Economics Society, Working paper No. 1805.

Stockhammer, E. - Stehrer, R. (2011), "Goodwin or Kalecki in demand? Functional income distribution and aggregate demand in the short run", Review of Radical Political Economics, Vol. 43, No. 4, pp. 506-522.

Streeck, W. (2011), “The crises of democratic capitalism”, New Left Review, Vol. 71, pp. 5-29.

Tahoun, A. - Vasvari, F. P. (2016), "Political lending", Institute for New Economic Thinking Working Paper Series, No. 47.

Tripathi, M. - Ansolabehere, S. - Snyder Jr, J. M. (2002), "Are PAC Contributions and Lobbying Linked? New Evidence from the 1995 Lobby Disclosure Act", Business and Politics, Vol. 4, No. 2, pp. 131-155. 
